\title{
EFFECT OF MODIFYING CONCENTRATIONS OF CALCIUM AND MAGNESIUM ON in vitro DEVELOPMENT OF BANANA CV. PRATA-ANÃ (GENOMIC GROUP AAB)
}

\author{
EFEITO DA MODIFICAÇÃO DAS CONCENTRAÇÕES DE CÁLCIO E MAGNÉSIO \\ NO DESENVOLVIMENTO in vitro DE BANANEIRA CV. PRATA-ANÃ (GRUPO \\ GENÔMICO AAB)
}

\section{Filipe Almendagna RODRIGUES ${ }^{1}$; Renata Alves Lara Silva REZENDE ${ }^{2}$; Joyce Dória Rodrigues SOARES ${ }^{3}$; Luciana Alves Caldeira BRANT ${ }^{4}$; Tesfahun Alemu SETOTAW ${ }^{5}$; Moacir PASQUAL ${ }^{6}$, José Magno Queiroz LUZ}

1. Doutor em Agronomia/Fitotecnia, Universidade Federal de Lavras - UFLA, Lavras, MG, Brasil. filipealmendagna@yahoo.com.br; 2. Pós-doutoranda em Agronomia/Fitotecnia, UFLA, Lavras, MG, Brasil; 3. Professora, Doutora, Departamento de Agricultura, UFLA, Lavras, MG, Brasil; 4. Doutoranda em Agronomia/Fitotecnia, UFLA, Lavras, MG, Brasil; 5. Pós-doutorando em Agronomia/Fitotecnia, UFLA, Lavras, MG, Brasil; 6. Professor, Doutor, Departamento de Agricultura, UFLA, Lavras, MG, Brasil; 7. Professor, Doutor, Instituto de Ciências Agrárias - ICIAG - UFU, Uberlândia, MG, Brasil.

\begin{abstract}
Research suggests that the development of micropropagated banana plants can be improved by altering nutrient concentrations in the culture medium. The aim of this study was to evaluate the in vitro development of banana plants exposed to varying concentrations of calcium and magnesium sulfate. The shoot tips of banana cv. PrataAnã were inoculated in flasks (volume, $250 \mathrm{~cm}^{3}$ ) containing $50 \mathrm{~mL}$ of MS culture medium. The culture medium contained varying concentrations of $\mathrm{CaCl}_{2}\left(0,220,440,880 \mathrm{mg} \mathrm{L}^{-1}\right)$ and $\mathrm{MgSO}_{4}\left(0,185,370,740 \mathrm{mg} \mathrm{L}^{-1}\right.$. A completely randomized experimental design was employed, based on a $4 \times 4$ factorial scheme (four levels of $\mathrm{CaCl}_{2}$ concentration, and four of $\mathrm{MgSO}_{4}$ ). The MS culture medium containing $880 \mathrm{mg} \mathrm{L}^{-1}$ of $\mathrm{CaCl}_{2}$ but no $\mathrm{MgSO}_{4}$ showed the highest increment in the number of leaves (6.0). The highest number of roots was observed in the absence of $\mathrm{CaCl}_{2}$ and $\mathrm{MgSO}_{4}$ in the medium. Additionally, the shoot length was longer $(5.05 \mathrm{~cm})$ when the MS medium was supplemented with $185 \mathrm{mg} \mathrm{L}^{-1} \mathrm{of} \mathrm{MgSO}_{4}$. The optimum in vitro development of banana cv. Prata-Anã was obtained when the MS medium was supplemented with $880 \mathrm{mg} \mathrm{L}^{-1}$ of $\mathrm{CaCl}_{2}$ and $370 \mathrm{mg} \mathrm{L}^{-1}$ of $\mathrm{MgSO}_{4}$.
\end{abstract}

KEYWORDS: Musa spp. Tissue culture. Micropropagation. Mineral nutrition.

\section{INTRODUCTION}

In Brazil, one of the most cultivated and consumed fruits is the banana (REETZ et al., 2015). Brazil is the fourth largest producer of bananas after India, China, and the Philippines (OECD, 2015). Banana cultivation extends throughout all regions in Brazil, and the fruits provide a source of both income and food for producers (SILVA et al., 2003).

Currently, several banana cultivars are traditionally grown in Brazil (NOMURA et al., 2013). However, the cultivar Prata-Anã (genomic group $\mathrm{AAB}$ ) is most widely planted and consumed; it has a long tradition of cultivation in the country, and is well accepted by the market (DONATO et al., 2009).

It is difficult to expand the productivity of banana plantations using conventional methods, because the seedlings produced through conventional methods multiply at a low rate, and are also susceptible to diseases and pests (ROELS et al., 2005). Propagation using in vitro methods is however a viable alternative, since it enables fast multiplication of a large number of seedlings that are of high phytosanitary quality, and are genetically superior and uniform. Micropropagation is therefore more frequently used than conventional methods in banana production, and is preferred by producers because of the high cost-benefit relationship.

There is little information in the literature about the importance of mineral nutrients for the growth of banana plants in vitro (GRIBBLE et al., 2002). There are several studies on mineral nutrition and its effect on banana plant growth and development. However, Souza and Gonçalves (1996) note the absence of systematic studies on adequate nutrient composition in the culture medium for different genotypes of banana plants.

Banana is a nutrient-exigent plant, not only to facilitate rapid vegetative development, but also to ensure high biomass production and high levels of nutrient absorption. Synergism and antagonism between nutrients are well studied for banana. According to Borges (2004), the most researched interactions relating to banana plants concern 
potassium $(\mathrm{K})$, calcium $(\mathrm{Ca})$, and magnesium $(\mathrm{Mg})$. Paula et al. (2015) report that banana plants cultivated in vitro absorb less $\mathrm{K}$, and a similar quantity of $\mathrm{Ca}$ and $\mathrm{Mg}$ compared to plants cultivated ex vitro. However, it is fundamental to satisfactory in vitro development to maintain nutrient equilibrium in the culture medium.

The Murashige and Skoog (MS) culture medium is one of the most utilized, for either micropropagation or other biotechnology techniques, in growing banana (MURASHIGE; SKOOG, 1962). Calcium chlorate $\left(\mathrm{CaCl}_{2}\right)$, magnesium sulfate $\left(\mathrm{MgSO}_{4}\right)$, and potassium sulfate $\left(\mathrm{KH}_{2} \mathrm{PO}_{4}\right)$ have been identified as highly important reagents in the MS medium (WADA et al., 2015).

$\mathrm{Ca}$ and $\mathrm{Mg}$ are the most important macronutrients for the banana plant. $\mathrm{Ca}$ is an important component of its cell walls; it is involved in membrane permeability, ensuring continued transpiration with the loose of turgidity (RAVEN et al., 2007). According to Prado (2008), Ca plays a role in cell wall formation by increasing mechanical resistance, thus supporting the acclimatization phase of the plant. $\mathrm{Mg}$ is present in chlorophyll molecules, and in leaf cell vacuoles, the organelles that contain $10 \%$ of the total leaf Mg (MALAVOLTA, 2006). It is also a cofactor for various enzymes which act on phosphorylated substrates that are of great importance in energy metabolism. Additionally, $\mathrm{Mg}$ also stimulates hydrogenase, lyase, and mutase activity within the plant (MENGEL; KIRKBY, 1987).

Adelberg et al. (2013) indicated that an understanding of the relationship between nutrients is important to identifying the culture medium composition that best eliminates nutrient deficiency by optimizing micropropagation processes. In this context, modifying $\mathrm{CaCl}_{2}$ and $\mathrm{MgSO}_{4}$ in the culture medium could potentially improve development using micropropagation.

Based on this hypothesis, the objective of this study was to evaluate and compare the in vitro development of banana cv. Prata-Anã when submitted to different concentrations of $\mathrm{CaCl}_{2}$ and $\mathrm{MgSO}_{4}$.

\section{MATERIAL AND METHODS}

Shoot tips of banana cv. Prata-Anã (genomic group AAB) were inoculated in flasks (volume, $250 \mathrm{~cm}^{3}$ ) containing $50 \mathrm{~mL}$ of MS culture medium (MURASHIGE; SKOOG, 1962), supplemented by different concentrations of $\mathrm{CaCl}_{2}$ $\left(0,220,440\right.$, and $\left.880 \mathrm{mg} \mathrm{L}^{-1}\right)$, and $\mathrm{MgSO}_{4}(0,185$, 370 , and $\left.740 \mathrm{mg} \mathrm{L}^{-1}\right)$. In addition, $1.8 \mathrm{~g} \mathrm{~L}^{-1}$
Phytagel $^{\circledR}$ (Sigma-Aldrich Co., St. Louis, MO, USA) was added to the culture medium, and the $\mathrm{pH}$ was adjusted to 5.8 before it was autoclaved $\left(121^{\circ} \mathrm{C}\right.$, $1 \mathrm{~atm}$, for $20 \mathrm{~min}$ ). Subsequently, the flasks were maintained in the growth room and illuminated with white fluorescent light (OSRAM 20W), with an irradiation of $42 \mathrm{~W} \mathrm{~m}^{-2}, 16$-hour photoperiod, and temperature of $25 \pm 2{ }^{\circ} \mathrm{C}$.

A completely randomized experimental design was used, with a $4 \times 4$ factorial scheme (for the four concentration levels of $\mathrm{CaCl}_{2}$, and four of $\mathrm{MgSO}_{4}$ ). Twelve plants were used (four plants for three replications) for each treatment. The number of shoots, number of roots, aerial section length $(\mathrm{cm})$, root length $(\mathrm{cm})$, number of leaves, and plant fresh weight $(\mathrm{g})$ were evaluated after 45 days of culture.

The data recorded were subjected to an analysis of variance and means separation test. The data revealed a significant difference between treatments subsequently submitted for regression analysis. All the statistical analysis was performed using Sisvar statistical analysis software (FERREIRA, 2011).

\section{RESULTS AND DISCUSSION}

A significant interaction was observed between $\mathrm{CaCl}_{2}$ and $\mathrm{MgSO}_{4}$ levels for all the variables studied, except root length.

Figure 1 shows the standard behavior of in vitro cultured banana cv. Prata-Anã in the different treatments. The absence or use of a $220 \mathrm{mg} \mathrm{L}^{-1}$ level of $\mathrm{CaCl}_{2}$, when combined with different concentrations of $\mathrm{MgSO}_{4}\left(0,185,370,740 \mathrm{mg} \mathrm{L}^{-1}\right)$, resulting in leaves appearing burnt. This was probably due to $\mathrm{Ca}$ deficiency, leading to chlorosis and necrosis in the young leaves. It is important to note that the only source of $\mathrm{Ca}$ present in the MS medium was $\mathrm{CaCl}_{2}$, at a concentration of $440 \mathrm{mg} \mathrm{L}^{-}$ 1 .

As Ca has a low mobility, symptoms of its deficiency were very severe in new leaves and the meristematic regions, resulting in tissue damage to or death of these growing parts (EPSTEIN; BLOOM, 2005). According to Arruda et al. (2000), this low $\mathrm{Ca}$ mobility could be due to its high concentration in the middle lamella of cell walls, and in the external region of the plasmatic membrane. $\mathrm{Ca}$ also plays an important role in morphogenesis, due to its interaction with growth regulator substances associated with cytokinin, mainly in the area where differentiation occurs. It can also assist in the detoxication of high concentrations of other mineral elements in the plant 
tissues. $\mathrm{Ca}$ is transported through passive processes that are influenced by the respiration rate (MCCOWN; SELLMER, 1987). Therefore, the necrotic symptoms observed in the terminal shoots mostly occurred as a result of low respiratory activity in the explants cultivated in vitro. However, these symptoms can be prevented by environmental modification of the culture using gas exchange, or by increasing $\mathrm{Ca}$ levels in the culture medium.
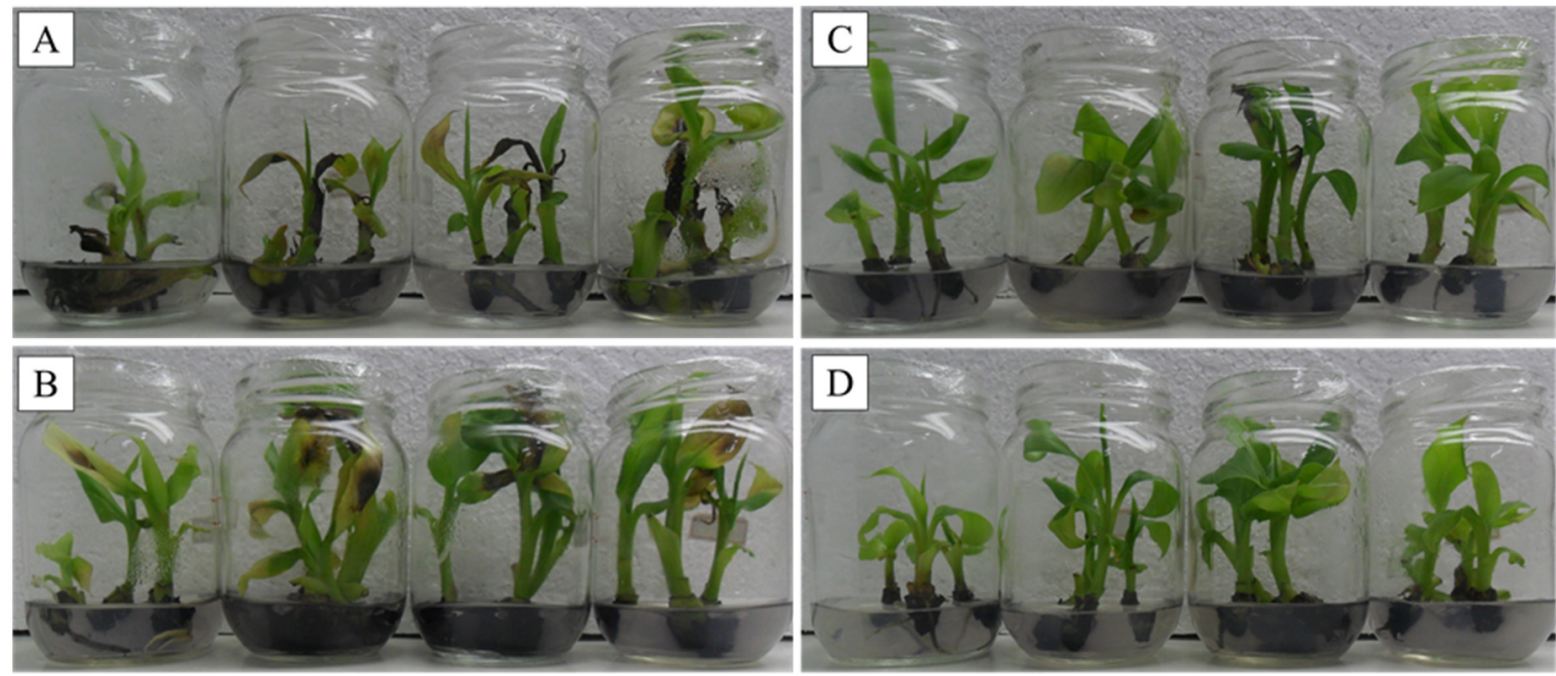

Figure 1. Role of $\mathrm{CaCl}_{2}$ and $\mathrm{MgSO}_{4}$ in the in vitro development of banana cv Prata-Anã: $\mathrm{A}-$ absence of $\mathrm{CaCl}_{2}$, with $0,185,370,740 \mathrm{mg} \mathrm{L}^{-1}$ of $\mathrm{MgSO}_{4} ; \mathrm{B}-220 \mathrm{mg} \mathrm{L}^{-1}$ of $\mathrm{CaCl}_{2}$, with $0,185,370,740 \mathrm{mg} \mathrm{L}^{-1}$ of $\mathrm{MgSO}_{4} ; \mathrm{C}-440 \mathrm{mg} \mathrm{L}^{-1}$ of $\mathrm{CaCl}_{2}$, with $0,185,370,740 \mathrm{mg} \mathrm{L}^{-1}$ of $\mathrm{MgSO}_{4} ; \mathrm{D}-880 \mathrm{mg} \mathrm{L}{ }^{-1}$ of $\mathrm{CaCl}_{2}$, with $0,185,370,740 \mathrm{mg} \mathrm{L}^{-1}$ of $\mathrm{MgSO}_{4}$.

Sarkar et al. (2005) also found limited Ca translocation rates in potato plants in an in vitro culture. Since the transport of $\mathrm{Ca}$ in the xylem is dependent on plant transpiration, high air humidity in the in vitro environment can induce Ca deficiency in the aerial parts of micropropagated plants. It is probable that, among all macronutrients, $\mathrm{Ca}$ is most sensitive to problems in translocation, thereby impacting plant growth (WHITE; BROADLEY, 2003)

In our study, chlorosis was observed in mature leaves. This supports the rapid translocation of $\mathrm{Mg}$ from mature to younger plant parts; the visual symptoms of $\mathrm{Mg}$ deficiency therefore first appear in more mature leaves (EPSTEIN; BLOOM, 2005), in contrast to $\mathrm{Ca}$, which accumulates in older organs due to its low mobility in the phloem (MALAVOLTA, 2006).

A significant influence on the number of shoots (Figure 2A) was observed at concentrations of $370 \mathrm{mg} \mathrm{L}^{-1}$ of $\mathrm{MgSO}_{4}$, when combined with the various $\mathrm{CaCl}_{2}$ concentrations. As the concentration of $\mathrm{CaCl}_{2}$ increased, the number of shoots per explant reduced, from a mean value of 2.43 shoots in the absence of $\mathrm{CaCl}_{2}$. In contrast to our findings for banana cv. Prata-Anã, Adelberg et al. (2013) showed that increases in the concentration of $\mathrm{CaCl}_{2}$ and $\mathrm{MgSO}_{4}$ promoted increased shoot numbers for turmeric (Curcuma longa $\mathbf{L}$.).
The number of roots (Figure 2B) reduced according to a quadratic form when $185 \mathrm{mg} \mathrm{L}^{-1}$ of $\mathrm{MgSO}_{4}$ was combined with increasing $\mathrm{CaCl}_{2}$ concentrations. The maximum number of roots (mean value 4.98) was observed in the absence of $\mathrm{CaCl}_{2}$. For ions to be absorbed through the plant roots, it is necessary to establish ion-root contact through the processes of mass flow, diffusion, and radicular interception (ZELAZNY; VERT, 2014). It is likely that, in our study, banana cv. Prata-Anã increased the number of roots in order to promote radicular interception and absorption of $\mathrm{Ca}$ in the presence of lower $\mathrm{Ca}$ concentrations in the growing medium. This is supported by a reduction of $33.33 \%$ in the number of roots when concentrations of $\mathrm{Ca}$ in the medium were increased.

A concentration of $370 \mathrm{mg} \mathrm{L}^{-1}$ of $\mathrm{MgSO}_{4}$ was observed to promote an increase in shoot length (Figure 2C) with increasing concentrations of $\mathrm{CaCl}_{2}$, achieving a maximum value of $5.76 \mathrm{~cm}$. In contrast, a concentration of $185 \mathrm{mg} \mathrm{L}^{-1}$ of $\mathrm{MgSO}_{4}$ promoted a reduction in shoot length.

The number of leaves (Figure 2D) increased in the absence of $\mathrm{MgSO}_{4}$, or at a concentration of $370 \mathrm{mg} \mathrm{L}^{-1}$ together with an increase in $\mathrm{CaCl}_{2}$ concentration. A reduction in the number of leaves was observed at concentration of $880 \mathrm{mg} \mathrm{L}^{-1}$ of $\mathrm{CaCl}_{2}$. 
(A)

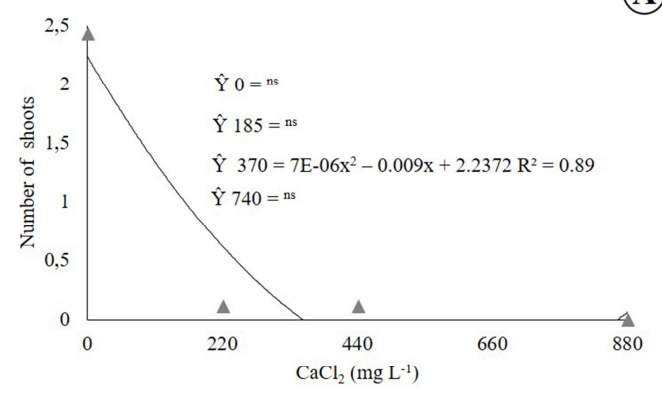

(C)

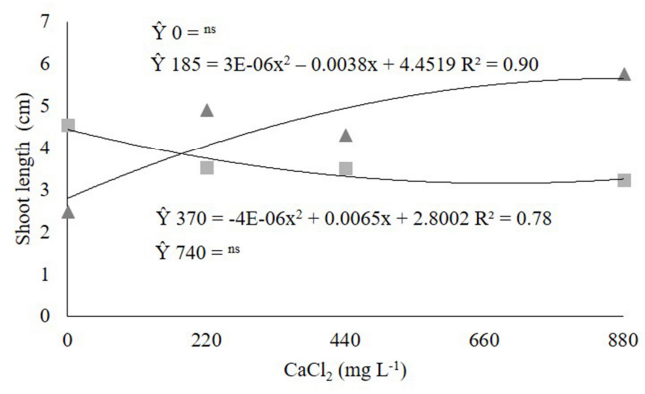

$\varpi 185 \mathrm{mg} \mathrm{L}^{-1} \mathrm{MgSO}_{4} \quad \Delta 370 \mathrm{mg} \mathrm{L}^{-1} \mathrm{MgSO}_{4}$
(A)

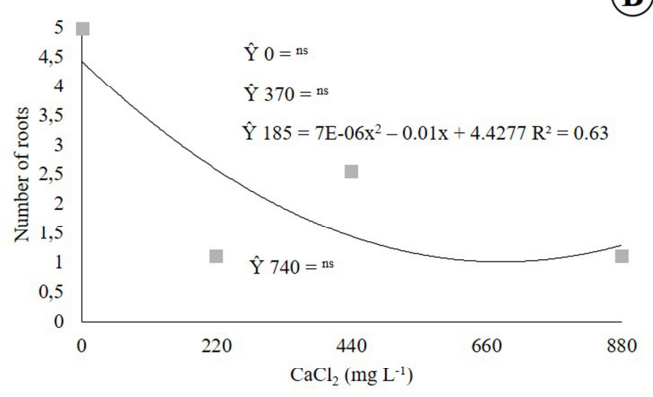

$185 \mathrm{mg} \mathrm{L}^{-1} \mathrm{MgSO}_{4}$

(D)

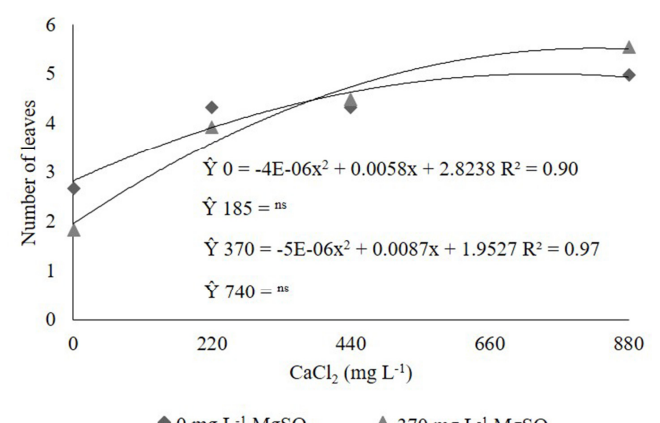

(E)

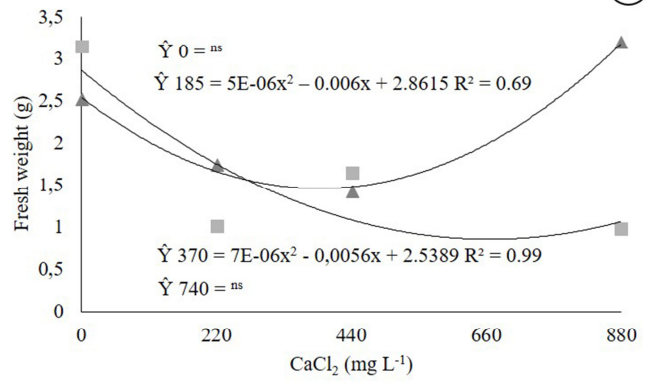

-185 $\mathrm{mg} \mathrm{L}^{-1} \mathrm{MgSO}_{4} \quad \Delta 370 \mathrm{mg} \mathrm{L}^{-1} \mathrm{MgSO}_{4}$

Figure 2. A) Number of shoots, B) number of roots, C) shoot length, D) number of leaves, and E) fresh weight of banana cv. Prata-Anã cultured in different concentrations of $\mathrm{CaCl}_{2}$ and $\mathrm{MgSO}_{4}$. Legend: $\mathrm{ns}=$ nonsignificant.

The fresh weight (Figure 2E) increased in a quadratic form when $370 \mathrm{mg} \mathrm{L}{ }^{-1}$ of $\mathrm{MgSO}_{4}$ was used, achieving a maximum value of $3.19 \mathrm{~g}$.

In this study, the optimum results for number of shoots, shoot length, number of leaves, and fresh weight were observed when using concentrations of $880 \mathrm{mg} \mathrm{L}^{-1}$ of $\mathrm{CaCl}_{2}$, and $370 \mathrm{mg}$ $\mathrm{L}^{-1}$ of $\mathrm{MgSO}_{4}$. This is demonstrated in Figure 2. In summary, our findings suggest that an MS medium with $\mathrm{MgSO}_{4}$ at its original concentration (370 $\mathrm{mg} \mathrm{L}^{-}$ $\left.{ }^{1}\right)$, but with twice the concentration of $\mathrm{CaCl}_{2}(880$ $\mathrm{mg} \mathrm{L}{ }^{-1}$ ), is the protocol that favors the optimum in vitro development of banana.

\section{CONCLUSION}

The optimum in vitro development of banana cv. Prata-Anã was obtained using an MS culture medium, containing $880 \mathrm{mg} \mathrm{L}^{-1}$ of $\mathrm{CaCl}_{2}$ and $370 \mathrm{mg} \mathrm{L}^{-1}$ of $\mathrm{MgSO}_{4}$.

RESUMO: Pesquisas sugerem que o desenvolvimento de plantas de bananeira podem ser melhoradas pela alteração das concentrações no meio de cultura. O objetivo deste estudo foi avaliar o desenvolvimento in vitro de bananeira submetida a diferentes concentrações de cloreto de cálcio e sulfato de magnésio. Ápices caulinares de bananeira 
cv. Prata-Anã foram inoculados em frascos (volume, $250 \mathrm{~cm}^{3}$ ) contendo $50 \mathrm{~mL}$ de meio de cultura MS. O meio de cultura contendo diferentes concentrações de $\mathrm{CaCl}_{2}\left(0,220,440\right.$ e $\left.880 \mathrm{mg} \mathrm{L}^{-1}\right)$ e $\mathrm{MgSO}_{4}\left(0,185,370,740 \mathrm{mg} \mathrm{L}{ }^{-1}\right) . \mathrm{O}$ delineamento experimental foi inteiramente casualizado, em esquema fatorial $4 \times 4$ (quatro concentrações de $\mathrm{CaCl}_{2} \mathrm{e}$ quatro de $\mathrm{MgSO}_{4}$ ). $\mathrm{O}$ meio $\mathrm{MS}$ contendo $880 \mathrm{mg} \mathrm{L}^{-1}$ de $\mathrm{CaCl}_{2}$ na ausência de $\mathrm{MgSO}_{4}$ proporcionou maior incremento no número de folhas $(6,0)$. Maior número de raiz foi observado na ausência de $\mathrm{CaCl}_{2}$ e $\mathrm{MgSO}_{4}$ no meio. Além disso, maior comprimento de parte aérea $(5,05 \mathrm{~cm})$ foi obtido em meio MS suplementado com $185 \mathrm{mg} \mathrm{L} \mathrm{L}^{-1} \mathrm{de}_{\mathrm{MgSO}}$. O melhor desenvolvimento in vitro de bananeira cv. Prata-Anã foi obtido em meio MS suplementado com $880 \mathrm{mg} \mathrm{L}^{-1} \mathrm{de} \mathrm{CaCl}_{2} \mathrm{e}$ $370 \mathrm{mg} \mathrm{L}^{-1}$ de $\mathrm{MgSO}_{4}$.

PALAVRAS CHAVE: Musa spp. Cultura de tecidos. Micropropagação. Nutrição mineral.

\section{REFERENCES}

ADELBERG, J.; DRIESSE, T.; HALLORAN, S.; BRIDGES, W. C. Relationships between nutrients and plant density in liquid media during micropropagation and acclimatization of turmeric. In Vitro Cellular \& Developmental Biology - Plant, v. 49, n. 6, p. 724-736, 2013. https://doi.org/10.1007/s11627-013-9576-y

ARRUDA, S. C. C.; SOUZA, G. M.; ALMEIDA, M.; GONÇALVES, A. N. Anatomical and biochemical characterization of the calcium effect on Eucalyptus urophylla callus morphogenesis in vitro. Plant Cell, Tissue and Organ Culture, v. 63, n. 2, p. 143-154, 2000. https://doi.org/10.1023/A:1006482702094

BORGES, A.L. Interação entre nutrientes em bananeira. Banana em Foco, v. 55, p. 2-4, 2004.

DONATO, S. L. R.; ARANTES, A. M.; SILVA, S. O.; CORDEIRO, Z. J. M. Comportamento fitotécnico da bananeira 'Prata-Anã' e de seus híbridos. Pesquisa Agropecuária Brasileira, Brasília, v. 44, n. 12, p. 16081615, 2009. https://doi.org/10.1590/S0100-204X2009001200007

EPSTEIN, E.; BLOOM, A. Mineral nutrition of plants: principles and perspectives. $2^{\text {nd }}$ ed Sunderland: Sinauer Associates, 2005. 380p.

FERREIRA, D.F. Sisvar: a computer statistical analysis system. Ciência e Agrotecnologia, v. 35, n. 6, p. 1039-1042, 2011. https://doi.org/10.1590/S1413-70542011000600001

GRIBBLE, K.; CONROY, J. P.; HOLFORD, P.; MILHAM, P. J. In vitro uptake of minerals by Gypsophila paniculata and hybrid eucalypts, and relevance to media mineral formulation. Australian Journal of Botany, v. 50, n. 6, p. 713-723, 2002. https://doi.org/10.1071/BT02018

MALAVOLTA, E. Manual de nutrição mineral de plantas. São Paulo: Editora Agronômica Ceres, 2006. 638p.

MENGEL, K.; KIRKBY, E. A. Principles of plant nutrition. $4^{\text {th }}$ ed. Bern: International Potash Institute, 1987. $655 \mathrm{p}$.

MCCOWN, B. H.; SELLMER, J. C. General media and vessels suitable for wood plant culture. In: BONGA, J. M.; DURZAN, D. J. (eds.) Cell and tissue culture in forestry, Volume 1. General principles and biotechnology. Dordrecht: Martinus Nijhoff, 1987. p. 4-16.

MURASHIGE, T.; SKOOG, F. A revised medium for rapid growth and bio assays with tobacco tissue cultures. Physiologia Plantarum, v. 15, n. 3, p. 473-497, 1962. https://doi.org/10.1111/j.1399-3054.1962.tb08052.x

NOMURA, E. S.; DAMATTO JUNIOR, E. R.; FUZITANI, E. J.; AMORIM, E. P.; SILVA, S. de O. Avaliação agronômica de genótipos de bananeiras em condições subtropicais, Vale do Ribeira, São Paulo - Brasil. Revista Brasileira de Fruticultura, Jaboticabal, v. 35, n. 1, p. 112-122, 2013. 
OECD/Food and Agriculture Organization of the United Nations. OCDE-FAO agricultural outlook 20152024. Paris: OECD Publishing, 2015. 54p.

PAULA, Y. C. M.; PASQUAL, M.; PIO, L. A. S.; PINHO, P. J.; SANTOS, D. N. Micropropagation of banana under different concentrations of potassium and magnesium. Tecnologia \& Ciência Agropecuária, v. 9, n. 3, p. 43-47, 2015.

PRADO, R. M. Nutrição de plantas. São Paulo: Editora Unesp, 2008. 407p.

RAVEN, P. H.; EVERT, R. F.; EICHHORN, S. E. Biologia vegetal. $7^{\text {th }}$ ed. Rio de Janeiro: Guanabara Koogan, 2007. 856p.

REETZ, E. R.; KIST, B. B.; SANTOS, C. E.; CARVALHO, C. DRUM, M. Anuário brasileiro da fruticultura 2015. Santa Cruz do Sul: Editora Gazeta, 2015. 104p.

ROELS, S.; ESCALONA, M.; CEJAS, I.; NOCEDA, C.; RODRIGUEZ, R.; CANAL, M. J.; SANDOVAL, J.; DEBERGH, P. Optimization of plantain (Musa AAB) micropropagation by temporary immersion system.

Plant Cell, Tissue and Organ Culture, v. 82, n. 1, p. 57-66, 2005. https://doi.org/10.1007/s11240-004-6746-y

SARKAR, D.; PANDEY, S. K.; CHANEMOUGASOUNDHARAM, A. The role of calcium nutrition in potato (Solanum tuberosum) microplants in relation to minimal growth over prolonged storage in vitro. Plant Cell, Tissue and Organ Culture, v. 81, n. 2, p. 221-227, 2005. https://doi.org/10.1007/s11240-004-5213-0

SILVA, S. O.; GASPAROTTO, L.; MATOS, A. P.; CORDEIRO, Z. J. M.; FERREIRA, C. F.; RAMOS, M. M.; JESUS, O. N. Programa de melhoramento de bananeira no Brasil: resultados recentes. Cruz das Almas: Embrapa Mandioca e Fruticultura, 2003. 36p.

SOUZA, G. M.; GONÇALVES, A. N. Otimização de meio de cultura para a bananeira (Musa cavendishii L.). Scientia Agricola, v. 53, n. 1, p. 51-59, 1996. https://doi.org/10.1590/S0103-90161996000100007

WADA, S.; MAKI, S.; NIEDZ, R. P.; REED, B. M. Screening genetically diverse pear species for in vitro $\mathrm{CaCl}_{2}, \mathrm{MgSO}_{4}$ and $\mathrm{KH}_{2} \mathrm{PO}_{4}$ requirements. Acta Physiologiae Plantarum, v. 37, n. 63, p. 1-10, 2015. https://doi.org/10.1007/s11738-014-1754-y

WHITE, P. J.; BROADLEY, M. R. Calcium in plants. Annals of Botany, v. 92, n. 4, p. 487-511, 2003. https://doi.org/10.1093/aob/mcg164

ZELAZNY, E.; GRÉGORY, V. Plant nutrition: root transporters on the move. Plant Physiology, v. 166, n. 2, p. 500-508, 2014. https://doi.org/10.1104/pp.114.244475 